\title{
Odpowiedzialność gminy za infrastrukturę techniczną i jej stan
}

\author{
\# infrastruktura techniczna \# odpowiedzialność cywilna \# gmina \# zarządzanie \# zadania \\ własne gminy \# transport
}

\# technical infrastructure \# liability \# commune \# management \# communes' own tasks \#

transport

Infrastruktura techniczna jako część majątku narodowego nieodzownie kojarzy się z pojęciem infrastruktury nieodzownej, bez której niemożliwe byłoby funkcjonowanie gminy. Ta, poprzez swoje zadania własne, realizuje bowiem kluczowe potrzeby społeczności lokalnej, planując, budując i utrzymując w należytym stanie infrastrukturę techniczną w postaci dróg czy sieci wodno-ściekowych. Jednakże realia XXI wieku w Polsce okazują się niekiedy brutalne dla obywatela i zaniedbania z zakresu właśnie utrzymania owej infrastruktury powodują powstanie odpowiedzialności na gruncie prawa cywilnego po stronie zarządcy infrastruktury technicznej. Problematyczne okazuje się natomiast ustalenie tego podmiotu, jako że obecnie każda gmina może w odmienny sposób powierzać wykonywanie zadań z jej zakresu, celem domniemanej bardziej wydajnej organizacji pracy w związku z infrastrukturą techniczną. W niniejszej pracy dokonana została analiza odpowiedzialności w przypadku infrastruktury technicznej, wraz z ustaleniem katalogu przykładowych podmiotów, które w świetle obecnych praktyk takową zarządzają. Postawione zostały również postulaty de lege ferenda, które mogą doprowadzić do ujednolicenia sposobu określania podmiotu zarządzającego danym elementem infrastruktury technicznej.

Technical infrastructure as a part of national assets is commonly associated with the term of indispensable infrastructure, without which normal functioning of a commune would be impossible. The commune, by realizing its own tasks, fulfills the key needs of the local community, by planning, building and maintaining the technical infrastructure in the form of roads or sewage networks in a sustainable condition. Nevertheless, the reality of XXI century Poland is often harsh for the citizen, as negligence in maintenance leads to the rise of liability on behalf of the

Miasto. Pamięć i Przyszłość 3/2 (2018) ISSN 2543-621X

\section{OPEN ACCESS}

Citation: Białas M., Odpowiedzialność gminy za infrastrukturę techniczną i jej stan, "Miasto. Pamięć i Przyszłość", $3 / 2$ (2018).

https://doi.org/10.26774/mpp.81

Editor: Jerzy Korczak

Received: October, 2018

Accepted: December, 2018

Published: December, 2018

Copyright: @ Ośrodek „Pamięć i Przyszłość" This is an open access article distributed under the terms of the Creative Commons Attribution-ShareAlike Licence, which permits unrestricted use, distribution, and reproduction in any medium, provided the original author and source are credited, with indications if any changes are made. All derivative works must be licensed under the same licence. (c) $\underset{\mathrm{BY}}{\mathrm{SP}}$ 
administrator of the technical infrastructure in question. Moreover, the issue of revealing who exactly is the administrator is ever the more prevalent, as communes are able to transfer their own tasks in regard to technical infrastructure onto third parties, in order to reach, what subjectively is seen as a rise in efficiency of organization in relation with the technical infrastructure. In this publication the analysis of responsibility was conducted, along with an attempt to list exemplary third parties, which currently manage technical infrastructure. De lege ferenda postulates were also made, aiming to unify the method of specifying the third party responsible for a given element of technical infrastructure.

Maciej Białas - student studiów stacjonarnych na kierunku prawo na Wydziale Prawa, Administracji i Ekonomii Uniwersytetu Wrocławskiego , członek Koła Naukowego Prawa Publicznego „Imperium” 


\section{Wstęp}

Jednym z fundamentalnych mechanizmów prawidłowego funkcjonowaniu każdej gminy w Polsce jest infrastruktura, przez którą rozumie się pewną część majątku narodowego - zbiór określonych sieci budynków i układów nieodnoszących się bezpośrednio do produkcji dóbr materialnych, jednakże niezbędnych do realizacji samego procesu produkcyjnego'. Chodzi tutaj zatem o takie części składowe majątku gminy, które służą zapewnieniu dostatecznego standardu bytowego mieszkańców. Wraz z nadejściem XXI wieku oraz ciągle nabierającym impetu postępem technologicznym, infrastruktura stała się zarazem jednym z najszybciej starzejących się i wymagających stosunkowo największej uwagi elementów stanowiących część skupienia zadań własnych gminy, w rozumieniu ustawy z dnia 8 marca 1990 r. o samorządzie gminnym² (dalej jako: „u. sam gm.”). To z kolei, ze względu na konieczność ponoszenia dużych nakładów, wiąże się niekiedy z doprowadzeniem omawianej infrastruktury do stanu, który

Miasto. Pamięć i Przyszłość 3/2 (2018) ISSN 2543-621X powoduje np. wystąpienie szkody po stronie osoby trzeciej, warunkując konieczność przyjrzenia się problematyce odpowiedzialności gminy za infrastrukturę, w tym i techniczną, oraz jej stan. Ta, w przeciwieństwie do dominujących publicznoprawnych regulacji w sferze jednostek samorządu terytorialnego, stanowi odejście w kierunku prawa cywilnego, co zostanie szeroko omówione na gruncie niniejszej publikacji. Rozpatrzone zostaną również kwestie ustalenia podmiotu, który w ramach struktury danej gminy należy uznać za bezpośrednio odpowiedzialny za infrastrukturę, a także jej stan, jako że praktyka wskazuje na znaczne różnice, rodzące problemy po stronie przeciętnie zorientowanego w obowiązujących przepisach prawa mieszkańca.

\section{Infrastruktura techniczna w gminie}

Od pojęcia infrastruktury należy odróżnić wąsko rozumianą infrastrukturę techniczną: w jej ramach mieszczą się urządzenia, sieci przesyłowe i związane z nimi obiekty świadczące

1. Infrastruktura techniczna a rozwój miasta, red. D. Stawisz, Łódź 2005, s. 7.

2. Dz.U. z 2018 r. poz. 994 z późn. zm. 
usługi dla danej jednostki, np. miasta³, w zakresie których mieszczą się z kolei zadania z zakresu energetyki, ciepła, wody, gospodarki ściekami i odpadami, transportu czy teletechniki, gdzie w szczególności chodzi o ich dostarczanie. Opisując infrastrukturę techniczną, można pokusić się o użycie autorskiego sformułowania infrastruktury nieodzownej, przez którą rozumieć należy wszelkie fundamentalne urządzenia i systemy do zarządzania gminą, stosując tutaj szerokie pojęcie zarządzania jako działania skierowanego na całości organizacyjne, polegające na osiągnięciu zamierzonych celów ${ }^{4}$ Infrastruktura ta ma więc na celu stricte zapewnienie ciągłości komfortu i bezpieczeństwa bytowego mieszkańców, wymagając tym samym wprowadzenia racjonalnego systemu zarządzania jej częściami składowymi oraz sformułowania procedur kontrolnych, celem monitorowania jest stanu.

Pojęcie infrastruktury technicznej nie jest wyłącznie wytworem dorobku doktryny prawa, gdyż zostało ono explicite użyte przez ustawodawcę m.in. w ustawie z dnia 21 sierpnia 1997 r. o gospodarce nieruchomościami. Ta w art. 143 ust. 2 traktuje o budowie urządzeń infrastruktury technicznej5, wprowadzając katalog takich działań, do których zalicza się:

1) budowę dróg,

2) wybudowanie pod ziemią, na ziemi albo nad ziemią, przewodów lub urządzeń:

a) wodociągowych,

3. Infrastruktura techniczna i usługi komunalne w ag/omeracji poznańskiej, red. T. Kaczmarek, Poznań 2011, s. 9.

4. Zarządzanie, [w:] Słownik języka polskiego PWN [online], http:// sjp.pwn.pl/szukaj/zarządzanie [dostęp: 06.07.2018].

5. Dz.U. z 2018 r. poz. 121 z późn. zm.

6. Dz.U. z 2018 r. poz. 994 z późn. zm. b) kanalizacyjnych,

c) ciepłowniczych,

d) elektrycznych,

e) gazowych,

f) telekomunikacyjnych.

Źródła tak dokładnej regulacji przez ustawodawcę pojęcia infrastruktury technicznej należy dopatrywać się w jego korelacji z zadaniami własnymi gminy, określonymi w u. sam. gm., która w art. 7 wymienia ${ }^{6}$ niektóre z nich, a mianowicie zadania obejmujące sprawy:

1) gminnych dróg, ulic, mostów, placów oraz organizacji ruchu drogowego.

2) wodociągów i zaopatrzenia w kanalizację, usuwania i oczyszczania ścieków komunalnych, utrzymania czystości i porządku urządzeń sanitarnych, wysypisk i unieszkodliwiania odpadów komunalnych, zaopatrzenia w energię cieplną, elektryczną oraz gaz.

Widoczne jest zatem, że ustawodawca w sposób celowy i jednoznaczny wpisał w zakres zadaniowy gminy kwestie związane wprost z infrastrukturą techniczną, cedując na nią tym samym odpowiedzialność za wszelkie sprawy publiczne, dotyczące życia mieszkańców. Do spraw tych należy zaliczyć przede wszystkim szeroko pojętą gospodarkę komunalną (np. budowa i utrzymanie sieci wodociągowej), a także aspekty związane z drogami i transportem zbiorowym (np. budowa, remont czy oświetlenie dróg gminnych).

Z perspektywy gminy jako jednostki samorządu terytorialnego, prawidłowe wykonywanie zadań własnych z zakresu infrastruktury

Miasto. Pamięć i Przyszłość 3/2 (2018) ISSN 2543-621X 
technicznej niesie ze sobą wielopłaszczyznowe, pozytywne efekty. W pierwszej kolejności wymienić należy fakt, że gmina realizująca poprawnie powyższe zadania zapewnia swoje prawidłowe funkcjonowanie, jako że ciężko jest sobie wyobrazić jej sprawne funkcjonowanie np. bez wydajnego systemu drogowego czy kanalizacyjnego. Poniekąd dalszym etapem jest poprawianie jakości życia w samej gminie, która poprzez odpowiednie finansowanie zadań z zakresu infrastruktury technicznej ma możliwość np. jej usprawnienia, co może przełożyć się również na wysoce pożądane zjawisko, jakim jest wzrost atrakcyjności gminy wśród potencjalnych mieszkańców i inwestorów. Ponadto istnieje wiele zjawisk bezpośrednio zagrażających rozwojowi gmin, do których doktryna zalicza m.in. niewydolność komunikacyjną, będącą efektem chociażby złego zarządzania infrastrukturą techniczną ${ }^{8}$. Jest to szczególnie ryzykowne, gdyż efektywny transport wpływa m.in. na wzrost jakości świadczonych usług i większe możliwości wyboru formy i sposobu przewozu pasażerów i towarów, co wpływa np. na poprawę standardu życia`. Przykładów dziatania proaktywnego gminy, która poczyniła inwestycje w infrastrukturę techniczną celem zachęcenia przedsiębiorstw do otwarcia zakładów na jej terenie nie trzeba szukać daleko - w całej Polsce znaleźć można dziesiątki przykładów dwa z nich występują w okolicach Wrocławia. Chodzi tutaj mianowicie o Gminę Siechnice, która korzystając ze swojego położenia - de facto na planie drogi krajowej nr 94, rozwinęła

Miasto. Pamięć i Przyszłość 3/2 (2018) ISSN 2543-621X 99 teren przemysłowy, inwestując w rozwój infrastruktury drogowej na jego obszarze, oraz o Gminę Kobierzyce, idealnie dopasowanej do uwarunkowań przebiegu węzła komunikacyjnego autostrady A4, która stworzyła na swoim terenie sieć dróg umożliwiającą budowę tzw. zagłębia handlowego w miejscowości Bielany Wrocławskie. Należy zaważyć, że obie te gminy podejmują kolejne działania na rzecz rozwoju swojej infrastruktury technicznej, przez dalszy rozwój sieci drogowej, inwestycje w gospodarkę ściekową, co pozwoli im w przyszłości na przyjmowanie kolejnych mieszkańców i przedsiębiorców, oferując im w tym samym czasie atrakcyjne warunki bytowo-inwestycyjne.

\section{Infrastruktura techniczna}

\section{a obowiązkowe zadania własne gminy}

Zgodnie z przepisem art. 7 ust. 2 ustawy z dnia 8 marca 1990 r. o samorządzie gminnym, ustawy określają, które zadania gminy mają charakter obowiązkowy ${ }^{10}$. Część z nich odnosi się bezpośrednio do kwestii związanych z infrastrukturą techniczną, a w tym ustawa z dnia 13 września 1996 r. o utrzymaniu porządku i czystości w gminach¹ oraz ustawa z dnia 16 grudnia 2010 r. o publicznym transporcie zbiorowym².

Przepisy upcg wprost wymieniają zadania gminy takie jak zapewnienie budowy, utrzymania, eksploatacji własnych lub wspólnych

\section{Infrastruktura techniczna a rozwój miasta, s. 9.}

8. L. Bylinko, Zarzadzanie infrastruktura transportową miasta, Bielsko-Biała 2015, s. 50.

9. A. Grzelakowski, Transport, [w.] Infrastruktura, red. Z. Brodecki, Warszawa 2004, s. 66

10. Dz.U. z 2018 r. poz. 994 z późn. zm., dalej w skrócie jako usg.

11. Dz.U. z 2018 r. poz. 11454, dalej w skrócie jako upcg.

12. Dz.U. z 2017 r. poz. 2136 z późn. zm., dalej w skrócie jako upt. 
z innymi gminami regionalnych instalacji do przetwarzania ścieków komunalnych lub stacji zlewnych, czy powinność gminy do nadzorowania gospodarowania odpadami komunalnymi, w tym realizację zadań powierzonych podmiotom odbierającym odpady komunalne od właścicieli nieruchomości³. Nawiązując do wcześniej wyrażonego poglądu o pojęciu infrastruktury nieodzownej, należy zauważyć jego związek z przywołaną regulacją. Uregulowanie zadań własnych gminy z zakresu instalacji do przetwarzania ścieków komunalnych lub stacji zlewnych, czy gospodarka odpadami stanowią bowiem kluczowy element funkcjonowania każdej z gmin, bez których te doznałyby całkowitego paraliżu. Nie sposób wyobrazić sobie gminę, gdzie nie funkcjonuje, nawet w podstawowym zakresie, system odprowadzania ścieków komunalnych, a odpady z gospodarstw domowych nie są regularnie usuwane ze śmietników i posesji. Niezrealizowanie zadań z zakresu infrastruktury technicznej wiązałoby się w tym wypadku np. z wystąpieniem zagrożenia epidemiologicznego, co dobitnie akcentuje nieodzowność tej infrastruktury.

Nie inaczej jest z przepisami upt, w której ustawodawca wyraźnie wskazał, że gmina obowiązkowo zajmować musi się budową, przebudową i remontem przystanków komunikacyjnych oraz dworców, których właścicielem lub zarządzającym jest gmina, a także wiat przystankowych lub innych budynków służących pasażerom - bez względu na kategorię drogi ${ }^{14}$. z pozoru kontrowersyjne wydaje się nałożenie na gminę aż tak szerokich obowiązków w tym zakresie, jednakże przy głębszej analizie ponownie dostrzega się pewną nieodzowność tego rozwiązania. Narzucenie konkretnych działań ma tutaj na celu zapewnienie minimum komunikacyjnego, aby umożliwić mieszkańcom bieżącą migrację z miejsca zamieszkania np. do miejsca pracy. Dzięki temu zabezpieczone zostają zarówno interesy prywatne, jak i interesy gminy, kosztem stosownych działań z jej strony. Ponownie więc mamy do czynienia z pojęciem infrastruktury technicznej jako infrastruktury nieodzownej, gwarantującej pewne koniecznie minimum, ale i zarówno perspektywę dla jednostki samorządu terytorialnego.

Obowiązkowe zadania własne gminy stanowią jasny wyraz znaczenia oraz roli infrastruktury technicznej w jej bieżącym funkcjonowaniu. Biorąc pod uwagę całokształt regulacji wprowadzonych przez ustawodawcę, zaryzykować można twierdzenie, że ten w sposób świadomy nadaje omawianej infrastrukturze nadrzędną rolę, rozpoznając jej doniosłość operacyjno-funkcjonalną w gminie. Realizacja zabezpieczenia tej roli odbywa się zatem w szerokim zakresie, zarówno przez budowę infrastruktury technicznej, jej planowania jak i późniejszego utrzymania w należytym stanie.

\section{Odpowiedzialność za infrastrukturę techniczną}

Kwestie odpowiedzialności, jak wspomniano wcześniej, są w znacznym stopniu przedmiotem regulacji cywilistycznej, znajdując swoje 
źródło w art. 415 ustawy z dnia 23 kwietnia 1964 r. - Kodeks cywilny'15. Mamy tutaj więc do czynienia z odpowiedzialnością ex delicto - na zasadzie winy, gdzie „ten kto z winy swej wyrządził drugiemu szkodę, obowiązany jest do jej naprawienia". Odrzucić należy pogląd, jakoby bezpośrednie zastosowanie miał tutaj art. 417 Kc, ponieważ traktuje on o realizacji czynności o władczym charakterze ${ }^{16}$, do których nie wydaje się możliwe zaliczenie normalnych zadań własnych gminy z zakresu np. bieżących napraw infrastruktury technicznej. Analizując natomiast treść przepisu art. 415 Kc, należy stwierdzić, że odpowiedzialność za infrastrukturę techniczną w wypadku szkody spoczywać będzie na jej zarządcy. Zdawałoby się, że stwierdzenie to stanowi swoiste wyczerpanie tematu odpowiedzialności, jednakże praktyka wskazuje na znaczący problem związany z kwestią ustalenia tego właśnie podmiotu. Ponadto w przypadku wielu gmin istnieje możliwość wystąpienie przesłanek odpowiedzialności z art. 429 Kc, aczkolwiek rozważania odnośnie culpa in contrahendo gminy w przypadku zlecenia wykonywania zadań własnych podmiotowi trzeciemu zasługują na obszerne omówienie w odrębnej publikacji.

Ustalenie zarządcy konkretnego elementu infrastruktury technicznej, w szczególności w przypadku gmin miejskich tworzących największe polskie aglomeracje, niekiedy stanowi nie lada wyzwanie. Z perspektywy przeciętnego obywatela wydawać się może, że wszelkie roszczenia kierować należy do organu wykonawczego i takie zjawisko można zaobserwować

Miasto. Pamięć i Przyszłość 3/2 (2018) ISSN 2543-621X 101 na wszelakich portalach, jak i stronach gmin, gdzie organy te udzielają odpowiedzi mieszkańcom¹7. Ci natomiast wszelkie zaniechania, np. w dbaniu o należyty stan dróg, notorycznie przypisują bezpośrednio do postaci wójta/burmistrza/prezydenta miasta, co wiąże się nie tyle z powszechną niewiedzą w zakresie podziału obowiązków w gminie, ale i z nieprzejrzystością oraz niejednolitością takich podziałów w Polsce.

Jako przykład przywołać można Gminę Wrocław oraz Gminę Gorzów Wielkopolski, których porównanie w jasny sposób ilustruje powyższy problem. Wybór owych gmin nie jest przypadkowy, jako że obie stanowią przykład gmin kluczowych, tj. będących stolicami właściwego dla siebie województwa. W pierwszej z gmin zarządcą infrastruktury torowej, drogowej, rowerowej czy oświetlenia jest Zarząd Dróg i Utrzymania Miasta - wydzielona organizacyjnie jednostka budżetowa18. Zakres zadań jej przekazanych wskazuje na fakt, że de facto wszelkie kwestie związane z infrastrukturą techniczną związaną z transportem leżą w zakresie jej kompetencji. W Gorzowie Wielkopolskim sytuacja ta kształtuje się odmiennie. Tam nie zdecydowano się na wydzielenie, mimo posiadania każdego z powyższych elementów infrastruktury technicznej, jednostki budżetowej do celów zarządczych, a zadania te powierzono konkretnemu wydziałowi Urzędu Miasta ${ }^{19}$. Należy tutaj zaznaczyć, że w porównywaniu gmin nie ma znaczenia ich

15. Dz. U. z 2016 r. poz. 380 z późn. zm.

16. Zob. Komentarz do art. 417 Kc, [w:] Kodeks cywilny. Komentarz, red. K. Pietrzykowski, Warszawa 2018.

17. Gmina Siechnice 2018, http://www.siechnice.gmina.pl/strona-2050-odpowiedzi_na_pytania_do_burmistrza.html, [dostęp: 06.07.2018].

18. Gmina Wrocław 2018, http://www.zdium.wroc.pl/ [dostęp: 06.07.2018]. 
rozmiar i skala stopnia rozbudowania omawianej infrastruktury. Niekiedy wybór podmiotów odpowiedzialnych za poszczególne jej elementy bywa zaskakujący, gdyż dokonywana jest fragmentacja zadań na np. zarządzanie infrastrukturą torową przez podmiot inny niż zajmujący się przejściami dla pieszych przez to torowisko przechodzących. Tym samym wyraźnie zarysowuje się problem braku jednolitego sposobu wyznaczania zarządcy wspomniany wyżej, uwidoczniony również w orzecznictwie.

Jednym z orzeczeń, mających duże znaczenie interpretacyjne dla omawianej problematyki, jest orzeczenie Sądu Okręgowego w Łodzi²o, w którym rozpoznawano apelację strony pozwanej, tj. Miejskiego Przedsiębiorstwa [...] sp. z o.o. $w \nmid$. Stan faktyczny sprawy prezentuje się jako wyjątkowo prozaiczny - powódka, przechodząc przez torowisko w miejscu przejścia dla pieszych, w miejscu nieodśnieżonym i oblodzonym, poślizgnęła się, upadła i doznała zwichnięcia rzepki stawu kolanowego. Trwały uszczerbek na zdrowiu powódki wyniósł 5\%., a ponadto była ona tymczasowo niezdolna do samodzielnej egzystencji i zmuszona do skorzystania z kosztownej pomocy osób trzecich. Postępowanie zostało przez nią zainicjowane celem uzyskania stosownego zadośćuczynienia za doznaną krzywdę, jaki m.in. odszkodowania za utracone zarobki. Już na tym etapie problematycznym okazało się ustalenie, kto ponosi odpowiedzialność za zaistniałą szkodę, a dokładniej, kto jest wspomnianym podmiotem zarządzającym

19. Urzad Miasta Gorzowa Wielkopolskiego 2018, http://bip. wrota.lubuskie.pl/umgorzow/369/3327/Wydzial_Drog/ [dostęp: 06.07.2018].

20. Wyrok Sądu Okręgowego w Łodzi z dnia 21.12.2016r., sygn. akt III Ca 1281/16, SAOS. infrastrukturą techniczną w postaci torowiska oraz znajdującego się na nim przejścia dla pieszych. Powódka dokonała tutaj błędnej interpretacji i swoje roszczenia skierowała zarówno przeciwko Miejskiemu Przedsiębiorstwu [...] sp. z o.o. w Ł. oraz Gminie Ł. - Zarząd Dróg i [...]. W toku postępowania dowodowego, mimo odmiennych twierdzeń pozwanego przedsiębiorstwa, powódka udowodniła, że miejsce jej upadku, czyli zdarzenia powodującego szkodę, mieściło się w obrębie przystanku tramwajowego, do którego bieżącego utrzymania na mocy umowy pomiędzy pozwanym a Gminą Ł., zobowiązało się pozwane przedsiębiorstwo. W zakresie jego zadań mieściło się utrzymanie czystości, odśnieżanie na powierzchniach przystanków w zakresie wynikającym z obowiązujących przepisów, a realizacja tych zadań mieściła się w kompetencjach podmiotów trzecich, z którymi pozwane przedsiębiorstwo zawarło umowy cywilnoprawne. Tym samym nienależyte wykonanie obowiązków przez Miejskie Przedsiębiorstwo [...] sp. z o.o. w Ł. prowadziło do logicznie łączącego się następstwa, jakim była szkoda doznana przez powódkę, co sąd uznał za słuszne. Należy zaznaczyć, że powództwo w części skierowanej przeciwko Gminie Ł. - Zarząd Dróg i [...] zostało oddalone jako niezasadne.

W omawianym orzeczeniu pojawia się zatem wspomniany wcześniej problem, którego szeroki zakres jest niejako odkrywany przez okoliczności wskazane w przytoczonym orzeczeniu. Gmina, zawierając w tym wypadku umowę ze spółką prawa handlowego, przekazała jej

Miasto. Pamięć i Przyszłość 3/2 (2018) ISSN 2543-621X 
obowiązki z zakresu zarządzania i utrzymania w należytym stanie infrastruktury technicznej, a podmiot ten takowe zadania powierzył jeszcze innym przedsiębiorcom. W tym samym czasie w Gminie $Ł$. funkcjonowała jednostka budżetowa w formie zarządu dróg, co doprowadziło do sytuacji, w przypadku której zarządzaniem infrastrukturą techniczną na ulicy wyposażonej w torowisko tramwajowe zajmowały się de facto dwa odrębne podmioty. Nie bez znaczenia pozostaje fakt, że kwestia odpowiedzialności za utrzymanie i ochronę torowiska wynika chociażby z art. 28a ustawy z dnia 21 marca 1985 r. o drogach publicznych ${ }^{21}$, co wskazuje na wolę ujednolicenia tej kwestii przez ustawodawcę. Nie eliminuje to jednak znacznej dywersyfikacji powierzania obowiązków z zakresu zarządzania różnym podmiotom w różnych gminach. Sytuacja ta jest wysoce niepożądana z perspektywy przeciętnego obywatela, który najprawdopodobniej nie będzie w stanie w prosty sposób określić, do kogo skierować swoje roszczenia, tak jak miało to miejsce w przypadku powódki w przytoczonym orzeczeniu. Należy postulować zatem wprowadzenie takich rozwiązań, które mogłyby doprowadzić czy to do ujednolicenia systemu zarządzania infrastrukturą techniczną w gminach, czy, co bardziej pasujące do charakteru gminy jako jednostki samorządu terytorialnego, wymogów dotyczących jednolitego i przejrzystego prezentowania podmiotów odpowiedzialnych, np. w formie wykazów w urzędach i na stronach internetowych gmin.

Miasto. Pamięć i Przyszłość 3/2 (2018) ISSN 2543-621X

103

\section{Problem infrastruktury energetycznej i kanalizacyjnej}

Wymienione w usg zadania własne gminy z zakresu gospodarki wodno-ściekowej i energetyki, podobnie jak i w przypadku dróg publicznych, podlegają daleko idącym podziałom co do podmiotów będących zarządcami powiązanej z nimi infrastruktury technicznej. Należy tu zaznaczyć, że w tym przypadku mamy do czynienia z infrastrukturą krytyczną, do której zalicza się m.in. systemy²2:

1) zaopatrzenia w energię i paliwa,

2) zaopatrzenie w żywność i wodę.

W interesie każdego państwa leży maksymalna ochrona takiej infrastruktury przed wszelkimi zagrożeniami, a w tym awariami oraz zdarzeniami, mogących zakłócać prawidłowe jej funkcjonowanie23. Infrastruktura techniczna, w szczególności w przypadku energetyki, jest zarazem znacznie bardziej skomplikowana i kosztowna, jako że wymaga znacznego zaangażowania środków na etapie zarówno planowania, jak i realizacji jej budowy. Dlatego właśnie szczególnie w przypadku energetyki gminy decydują się na wyłanianie z grona przedsiębiorców podmiotów-dostawców, zachowując część swoich uprawnień kontrolnych, zarazem cedując swoje obowiązki z zakresu tworzenia sieci energetycznej, jej utrzymania i zapewniania prądu mieszkańcom? Należy wyrazić pogląd, że takie działanie gminy jest wysoce pożądane, jako że nie wydaje się możliwe np. prowadzenie przez nią samą kompleksu elektrowni na

21. Dz. U. z 2017 r. poz. 2222 z późn. zm.

22. A. Tyburska, M. Nepelski., Ochrona infrastruktury krytycznej, Szczytno 2008, s. 16.

23. Tamże, s. 17. 
takim poziomie efektywności, jak robić może to wyspecjalizowane w tym zakresie przedsiębiorstwo energetyczne. Z perspektywy mieszkańca jego sytuacja bytowa poprawia się, jako że korzysta on z rozwiązań dostarczanych przez podmiot profesjonalny, a gmina zachowuje w tym samym czasie swój wpływ na ten podmiot przez odpowiednie kształtowania m.in. swojej polityki energetycznej.

Na marginesie należy wspomnieć jednak, że pojawiają się już w Polsce pierwsze gminy takie jak Wola Uhruska, które produkują własny prąd $^{24}$. Jest to jednak produkcja na małą skalę, a ten przekazywany jest następnie do podmiotu-dostawcy w gminie.

W przypadku systemów związanych z gospodarką wodno-ściekową sytuacja wygląda stosunkowo podobnie, ale tutaj poziom kontroli gmin jest zasadniczo wyższy. W ostatnim dwudziestoleciu w gminach w Polsce coraz częściej pojawia się zjawisko wyłączania jednostek zajmujących się tym elementem infrastruktury technicznej w formę jednoosobowych spółek gminnych. Za przykład posłużyć mogą chociażby Miejskie Przedsiębiorstwo Wodociągów i Kanalizacji SA w przypadku Gminy Wrocław25, Przedsiębiorstwo Wodociągów i Kanalizacji Sp.

24. Dziennik Wschodni 2015, https://www.dziennikwschodni.pl/chelm/gmina-produkuje-prad-i-bedzie-go-sprzedawac,n,150129869.html, [dostęp: 06.07.2018].

25. Gmina Wrocław 2018, http://bip.um.wroc.pl/artykuly/160/spoIki-gminy-wroclaw, [dostęp: 06.07.2018].

26. Urzad Miasta Gorzowa Wielkopolskiego 2018, http://bip.wrota. lubuskie.pl/umgorzow/231/596/WYKAZ_SPOLEK_I_FUNDACJI_Z_ UDZIALEM_MIASTA_GORZOWA_WLKP_OD_OAwg_stanu_na_ dzien_07_10_2014_r_OD_0A/, [dostęp: 06.07.2018].

27. Gmina Siechnice 2018, http://www.siechnice.gmina.pl/strona-65-jednostki_gminne.html [dostęp: 06.07.2018].

28. Infrastruktura techniczna a rozwój miasta, red. D. Stawasz, Łódź 2005, s. 10. z o.o. W Gorzowie Wlkp. ${ }^{26}$, czy Zakład Gospodarki Komunalnej Sp. z o.o. w Siechnicach²7. Takie działanie gminy wiąże się z wysokością uzyskiwanych przez te podmioty przychodów z prowadzonej działalności, pozwalających na nadanie im wyższej autonomii w zakresie zarządzania własnymi środkami trwałymi i zasobami finansowymi. W pewnym sensie wydaje się to również ułatwiać zadanie wyznaczenia zarządcy infrastruktury technicznej, która jest tutaj de facto w posiadaniu owych spółek, a ich nazewnictwo i zakres zadaniowy jest zasadniczo tożsamy pomiędzy gminami. Mimo, że jest to objaw wspomnianej wyżej fragmentaryzacji, to takowa w tym wypadku nie wydaje się być aż tak problematyczna dla mieszkańca, który w wypadku powstania szkody, np. z winy dostawcy wody do swojego mieszkania, może z łatwością określić podmiot odpowiedzialny za świadczenie takiej usługi.

\section{Problemy i perspektywy}

Infrastruktura techniczna jest wysoce podatna na rozwój technologiczny, ale i jednocześnie wiąże się z koniecznością ponoszenia dużych wydatków celem jej budowy i utrzymania28. System infrastrukturalny ulega zatem w czasie zmianom, a pewne jego elementy (jak np. fragmenty torowisk) nie odpowiadają współczesnym standardom czy to w zakresie świadczonych usług, czy zużycia ${ }^{29}$. Polska jest krajem, w którym w czasie ostatnich dwudziestu lat dokonał się godny podziwu postęp w zakresie infrastruktury technicznej - kraj zyskał setki kilometrów

Miasto. Pamięć i Przyszłość 3/2 (2018) ISSN 2543-621X 
autostrad, w miastach pojawia się coraz częściej oświetlenie LED, remontowane są torowiska, itd. W tym samym czasie z elementów omawianej na łamach tej pracy infrastruktury technicznej korzystają coraz to nowsze pojazdy, jak np. tramwaje marki Skoda 19T w przypadku Gminy Wrocław.

W wielu wypadkach okazuje się jednak, że istniejąca infrastruktura techniczna nie nadąża za postępem technologicznym, a jej zużycie jest spotęgowane przez używanie np. wspomnianych nowocześniejszych środków komunikacji. Prowadzi to do sytuacji, w której postępuje degradacja chociażby torowisk, co prowadzi do wykolejeń i wypadków, kończących się koniecznością wypłaty stosowanych odszkodowań i zadośćuczynienia za doznaną krzywdę ich uczestnikom. Należy zatem postawić zasadnicze pytanie: jak usprawnić zarządzanie infrastrukturą techniczną, aby ograniczyć konieczność sięgania przez osoby trzecie do odpowiedzialności za jej nienależyty stan? Odpowiedzią wydaje się być postulat wdrażania kompleksowych systemów zarządzania i planowania chociażby

Miasto. Pamięć i Przyszłość 3/2 (2018) ISSN 2543-621X remontów, na co wskazuje m.in. NIK ${ }^{30}$. Tym sposobem środki, które mogłyby zostać celem spłaty roszczeń, należy przeznaczyć na to, na co powinny być przeznaczone - utrzymanie infrastruktury technicznej w stanie funkcjonalnym i gwarantującym jej poprawne wykorzystanie przez mieszkańców i przedsiębiorców w gminie.

W przypadku sprawnego wdrażania wspomnianych rozwiązań, perspektywy dla infrastruktury technicznej w Polsce wydają się być zarysowane stosunkowo optymistycznie. Mimo konieczności czynienia duży nakładów finansowych i konstruowania budżetów gmin w taki sposób, aby maksymalnie wysoką kwotę dostępnych środków finansowych przeznaczyć np. na remonty dróg, poprawianie stanu infrastruktury pozwoli na uniknięcie jej dalszej degradacji. Długofalowo może to poskutkować rozwiązaniami tańszymi, a pozwalającymi na osiągnięcie efektów dostosowania jej przedmiotu do obecnych wymogów, bez konieczności angażowania większych ilości środków na budowę infrastruktury od podstaw.

29. Tamże, s. 11.

30. Najwyższa Izba Kontroli Delegatura w Warszawie, Informacja o wynikach kontroli działań podejmowanych na rzecz usprawnienia systemu transportowego w największych miastach w Polsce, Warszawa 2010, s. 5. 


\section{Literatura:}

- L. Bylinka, Zarządzanie infrastruktura transportowa miasta, Bielsko-Biała 2015.

- A. Grzelakowski, Transport, [w.] Infrastruktura, red.

Z. Brodecki, Warszawa 2004

- Infrastruktura techniczna a rozwój miasta, red. D. Stawasz, Łódź 2005.

- Infrastruktura techniczna i usługi komunalne w ag/omeracji poznańskiej, T. Kaczmarek, Poznań 2011.

- Kodeks cywilny. Komentarz, red. K. Pietrzkowski, Warszawa 2018.

- M. Kosmalski, Informacja o wynikach kontroli dziatań podejmowanych na rzecz usprawnienia systemu transportowego w największych miastach w Polsce, Warszawa 2010.

- A. Tyburska, M. Nepelski, Ochrona infrastruktury krytycznej, Szczytno 2008.

\section{Źródła internetowe:}

- Zarzadzanie, Słownik języka polskiego PWN [online], http://sjp.pwn.pl/szukaj/ zarządzanie
- Gmina Siechnice 2018, http://www.siechnice.gmina. pl/strona-2050-odpowiedzi_na_pytania_do_burmistrza.html

- Gmina Siechnice 2018, http://www.siechnice.gmina. pl/strona-65-jednostki_gminne.html

- Gmina Wrocław 2018, http://www.zdium.wroc.pl/

- Gmina Wrocław 2018, http://bip.um.wroc.pl/ artykuly/160/spolki-gminy-wroclaw

- Dziennik Wschodni 2015, https://www.dziennikwschodni.pl/chelm/gmina-produkuje-prad-i-bedzie-go-sprzedawac,n,150129869.html

- Urzad Miasta Gorzowa Wielkopolskiego 2018, http://bip.wrota.lubuskie.pl/umgorzow/369/3327/ Wydzial_Drog/

- Urzad Miasta Gorzowa Wielkopolskiego 2018, http://bip.wrota.lubuskie.pl/umgorzow/231/596/ WYKAZ_SPOLEK_I_FUNDACJI_Z_UDZIALEM_MIASTA_GORZOWA_WLKP__OD_OAwg_stanu_na_ dzien_07_10_2014_r_OD_OA/ 